УДК: $631.1: 779$

doi: $10.36359 /$ scivp.2019-20-2.54

\title{
МАРКЕТИНГОВА СКЛАДОВА ВИРОБНИЦТВА ВЕТЕРИНАРНИХ ПРЕПАРАТІВ ЗА ФУНКЦІОНУВАННЯ СИСТЕМИ УПРАВЛІННЯ ЇХ ЯКІСТЮ
}

\author{
В. О. Величко ${ }^{l}, \partial-р$ вет. наук, \\ А. В. Гримак ${ }^{2}$ канд. екон. наук, дочент, \\ Л. В. Курилас ${ }^{1}$, старший науковий співробітник, \\ T. С. Сенишина ${ }^{l}$, науковий співробітник \\ ${ }^{1}$ Державний науково-дослідний контрольний інститут ветеринарних препаратів \\ та кормових добавок \\ вул. Донецька, 11, м. Львів, 79019, Україна \\ ${ }^{2}$ Львівський національний університет ветеринарної медицини та біотехнологій \\ імені С. 3. Гжицького \\ вул. Пекарська, 50, м. Львів, 79010, Україна
}

Якість продукиії для ветмедищини, яку виробляють вітчизняні підприємства, ї̈ конкурентоспроможність, сьогодні на жаль, щее не є сильним і безапеляційним показником окремих підприємств. В той же час, необхідно визнати, що реформи, які проводяться у державі орієнтують виробників продукиії, в т. ч. і для ветеринарної медицини до переоиінки своїх застарілих тендениій в сторону удосконалення виробництв, щзо забезпечувало $б$ виробництво якісної $і$ безпечної продукиї для ветмедииини, йдеться в першу чергу про ветеринарні препарати, застосування яких ефективно забезпечувало б благополуччя тваринництва, птахівництва $i$ інших галузей, сприяло збереженню здоров'я людей $i$ екологічної рівноваги природнього середовища. Та й на самих підприємствах ветмедицини прийшло розуміння того, щьо саме впровадження ефективних систем управління якістю продукиії спроможне забезпечити стійке становище підприємств як у сфері виробництва так $і$ на ринку продукиї для ветмедицини. Звичайно, впровадження ефективної системи управління якістю вимагає високого професіоналізму, освоєння сучасних методів і технологій, а головне відповідного рівня кваліфікаиії персоналу. Це сприятиме тому, щзо вже сам процес розробки нових ветеринарних препаратів, відповідно $i$ їх апробаиії та виробництво буде базуватися на основних принципах системи якості, яка гарантуватиме, що вироблена продукція вироблясться $i$ контролюється відповідно до чіткого дотримання вимог нормативно-технічної документації і стандартів.

Ринок продукиї для ветмедицини уже орієнтує виробників на виробниџтво якісної, ефективної і конкурентоспроможної продукиії, по-новому, з врахуванням зарубіжного досвіду розглядати контакти з усіма суб'єктами, які причетні до виробництва $i$ поставок в обіг ветеринарних препаратів. В иъьому ваэлива роль відводиться маркетингу, який супроводить виробництво, допомагає його організувати і управляти не тільки виробництвом, а й збутом виробленої продукиії. Саме маркетинг може давати відповідні на ситуацію на ринку, планування асортименту продукиії, ï̈ характеристики, оцінки конкурентів, формує пропозиції і аналізує споживацький попит. Зрозуміло, що якість ветеринарних препаратів забезпечується комплексом заходів, в т. ч. і принципами ринку. Основні із них, зокрема $i$ механізми контролю якості ветпрепаратів регламентовані в Законах України «Про ветеринарну медицину», "Про основні засади державного нагляду (контролю) у сфері господарської діяльності», «Про захист прав споживачів», «Про вилучення з обігу, переробку, 
утилізащію, знищення або подальще використання неякісної $i$ небезпечної продукції», лічензійних умовах провадження господарської діяльності з виробництва ветеринарних препаратів, "Положення про реєстрацію (перереєстрацію) ветеринарних препаратів, субстаниій, готових кормів та кормових добавок в Україні». Основні параметри цих документів уже враховуються при гармонізачії законодавчих і нормативно-регламентуючих документів України.

Ключові слова: СИСТЕМА УПРАВЛІННЯ ЯКІСТЮ, ЛІЦЕНЗУВАННЯ, РИНОК, ПІДПРИЄМСТВО, ВИРОБНИЦТВО, КОНТРОЛЬ, МАРКЕТИНГОВИЙ СУПРОВІД.

Позитивним фактором $\epsilon$ те, що виробництво ветеринарних препаратів, їх реалізація і використання здійснюється через їх реєстрацію в Україні. Відповідно, вимоги щодо їх розробки, випробувань i виробництва уже взаємопов'язуються із впровадженням як національних так і міжнародних стандартів, в т. ч. ISO, а також вимог організації виробництва і контролю якості ветеринарних препаратів за належною виробничою практикою (GMP). Цього навчаються в ДНДКІ ветеринарних препаратів та кормових добавок фахівці підприємств ветмедицини через форму стажування, підвищення кваліфікації, участь в роботі фахових конференцій, семінарів, тренінгів.

Враховуючи вимоги сьогодення всі виробники і реалізатори ветпрепаратів повинні чітко уяснити, що саме стандартизація є одним і пріоритетних заходів, які напряму виливають на підвищення якості ветеринарних препаратів. I не тільки. Важливою вимогою стандартів, нормативно-регламентуючих документів до лікарських засобів є забезпечення їх ефективності. Препарат слід вважати ефективним тоді, коли поряд із клінічним видужуванням тварин зникає причина хвороби. Звичайно говорити про якість, безпечність і ефективність ветеринарних препаратів без оцінки шкідливості просто не можливо. Саме ці показники підтверджують нешкідливість препаратів для тварин, та й оцінку якості продуктів, які отримані від тварин, до яких застосовувались ветеринарні препарати.

Слід відзначити, що ветеринарна фармація є однією із перспективних галузей, в т. ч. і в Україні, є невід'ємною частиною їі економіки і ринку товарів і послуг. Ринок ветеринарної фармації доволі швидко насичується, вирівнюються якісні показники продукції вітчизняних підприємств ветмедицини. На цьому ринку помітною стає і конкурентна боротьба. Це обумовлює підвищення ролі маркетингових досліджень, маркетингового супроводу продукції підприємств ветмедицини, зокрема ветеринарних препаратів на фармацевтичному ринку. Саме вони надають своєчасну і вкрай важливу інформацію виробникам про пропозицію і попит на їх продукцію, рівень конкурентоспроможності, про можливості і ресурси партнерів на ринку. Рівно ж вони орієнтують споживачів щодо ринкових послуг, наявного асортименту продукції, надають необхідну інформацію щодо ринкових пропозицій. Маркетингові дослідження стають ключовими в розвитку інформаційних комунікацій між підприємством, яке виробляє продукцію для ветмедицини та споживачами, посередниками, реалізаторами тощо. За допомогою маркетингових досліджень підприємства ветмедицини підтримують зворотній зв'язок з ринком, завдяки чому можна контролювати просування продукції по ринковому ланцюгу, навіть створювати рекламу підприємствам, відповідно привертати увагу споживачів до його продукції, а також розкривати можливості збуту.

В питаннях маркетингового супроводу продукції конкретного підприємства важливо пам'ятати, що успіх залежатиме від розуміння і поведінки самого персоналу підприємства, хто виробляє продукцію.

Кваліфіковано відпрацьована система маркетингового супроводу є однією 3 дійових засобів зв'язку між виробниками продукції для ветмедицини та споживачами. Сьогодні, практично кожне друге підприємство, ветмедицини у своїх структурах мають підрозділи, або фахівців з маркетингу, за рахунок їх діяльності прибавляють успішності у діяльності ввірених підприємств. 
Позитивний зарубіжний та й вітчизняний досвід підтверджує, що маркетинг — це фактично система управління підприємством, яка базується на комплексному вивчені ринку i, в першу чергу запитів споживачів. Важливим для підприємств ветмедицини $є$ і те, що саме через маркетингову інформацію вони можуть відпрацьовувати механізм входження в ринок, утримання бажаної долі своєї продукції на ринку, практично бачити життєвий цикл своєї продукції, оцінювати в середовищі конкурентів. Все це, без сумніву, впливатиме і на організацію і здійснення заходів щодо якості і безпечності продукції для ветмедицини.

Тому оцінювати ефективність і якість ветеринарних препаратів необхідно в першу чергу з оцінки самого підприємства де вони виготовляються. Згідно з нормативними вимогами, на підприємстві повинні дотримуватись таких вимог:

- виробничий, технологічний процес, як і контроль якості повинні виконувати (забезпечувати) кваліфіковані працівники;

- всі виробничі, технологічні, контрольні операції (оцінка сировини і продукції, відбір проб на контрольних «точках» технологічного процесу, зберігання, маркування, транспортування тощо) повинні виконуватись відповідно до затверджених інструкцій i протоколюватися;

- вся сировина, в т. ч. субстанції повинні проходити карантинізацію;

- всі матеріали і продукція повинна зберігатись відповідно до затвердженого порядку, який передбачає розділення серій продукції і іїі переміщення на складі;

- не допускається одночасно проведення виробничих операцій з різними препаратами в одному і тому ж приміщенні;

- ветеринарні препарати і матеріали повинні бути захищені від мікробного і інших видів забруднень на всіх етапах виробництва;

- позначення або маркування на упаковках, обладнанні або приміщеннях повинні бути чіткими;

- у виробничі приміщення може входити персонал, який має право доступу до них;

- забороняється використання спеціального обладнання для виробництва продукції не ветеринарного призначення; продукції.

- відпрацьована система попередження перехресного забруднення сировини і готової

Слід враховувати нормативні вимоги і до пакувальних матеріалів і упаковки, а саме:

- не допускається пакування препаратів різного призначення близько одні від одних;

- перед початком пакування необхідно перевірити кількість продукції і пакувальних матеріалів, їх відповідність, зокрема і регламентуючими інструкціями;

- контролювати відповідність електронних штрих-кодів;

- маркування пакувальних матеріалів повинно бути чітким, стійким до впливу світла, вологи тощо;

- при контролюванні процесу пакування звертати увагу на зовнішній вигляд упаковки, iї комплектність, відповідність НД, зокрема нанесення написів;

- крім того, після завершення пакувальних робіт всі пакувальні матеріали, які залишились із нанесеними номерами серії і назви повинні бути вилучені із приміщення $\mathrm{i}$ знищені.

Щодо готової продукції слід дотримуватися правил:

- до отримання дозволу на реалізацію готова продукція повинна зберігатись під карантином згідно із затвердженими інструкцією умовами;

- після лабораторного підтвердження якості продукції вона передається на склад готової продукції, звідки і відпускається в обіг.

Враховуючи значимість продукції для підприємств, які виробляють продукцію для ветмедицини, затверджені особливі вимоги, які задекларовані в ліцензійних умовах, а саме:

- відповідність виробничих і складських приміщень нормативним вимогам; 
- забезпечення необхідним обладнанням відповідно до спеціалізації;

- відповідність технології виробництва ветпрепаратів НД і стандартами, технічним і технологічним регламентам;

- наявність компетентних лабораторій з посерійного, оперативного контролю якості і безпечності продукції;

- підготовлений персонал;

- ліцензіат повинен мати конкретні посадові інструкції для всіх спеціалістів i працівників, які безпосередньо задіяні у виробництві і контролі продукції (ветпрепаратів);

- спеціалісти і керівник підприємства не рідше одного разу на п'ять років повинні підвищувати свою кваліфікацію.

Названі умови $є$ складовою цілісної системи управління якістю продукції для ветмедицини, в т.ч. ветеринарних препаратів. Важливо, що кожен працівник підприємства ветмедицини повинен знати, який його внесок у процес забезпечення якості і ефективності продукції свого підприємства, чітко виконуючи свої посадові обов'язки. Адже кожна помилка, технологічне спрощення і упущення в контролюванні якості продукції можуть спровокувати втрату визнання на ринку продукції для ветмедицини через низьку ії якість і ефективність, відповідно, а звідси - збитковість підприємства і ущемлення інтересів працюючих в частині їх соціального захисту.

Тому виробник ветеринарних препаратів, та й загалом продукції для ветмедицини, повинен організувати їх виробництво так, щоб вони гарантовано відповідали своєму призначенню і вимогам, які до них ставляться в частині якості, безпечності і ефективності, а також не створювали ризиків для споживачів. Зрозумілим має бути те, що відповідальність за виконання цих вимог несуть безпосередньо керівника і всі працівники підприємства, як i постачальники та реалізатори продукції.

\section{В И С Н О В К И}

Забезпечення якості продукції ветмедицини, зокрема ветеринарних препаратів $є$ комплексним завданням, механізми реалізації яких мають бути регульовані цілісною системою управління якості продукції на виробництві. Тому, система управління якістю при виробництві ветеринарних препаратів повинна гарантувати: стандартів;

- ветеринарні препарати розроблені із врахуванням вимог нормативних документів,

- на всі виробничі і контрольні процедури розроблена нормативно-регламентуюча документація;

- відповідальність і чітке дотримання обов'язків всіма працівниками підприємства виробника і реалізатора;

- чіткий контроль проміжної продукції на “точках" технологічного циклу”;

- контролювання готової продукції відповідно до затверджених, валідованих методик;

- дотримання вимог щодо зберігання і подальшого обігу продукції ветмедицини;

- проведення періодичних внутрішніх аудитів на предмет дотримання підприємствомвиробником законодавчих і нормативно-регламентуючих вимог із забезпечення виробництва якісних і безпечних препаратів для ветеринарної медицини;

- організація маркетингового супроводу ветеринарних препаратів на ринку продукції для ветмедицини. Практика підтверджує, що маркетинг і управління якістю продукції — дві взаємодоповнюючі форми, які регуляторно впливають на дійсний стан і перспективи, щодо виробництва і обігу продукції для ветмедицини;

- успіх обігу продукції вітчизняних підприємств ветмедицини на ринку в значній степені залежить від знання і вмілого застосування ефективних заходів оцінки ринку, запитів споживачів і рівня конкурентних відносин. 


\title{
MARKETING COMPONENT PRODUCTION OF VETERINARY MEDICINES FOR FUNCTIONING OF THE MANAGEMENT SYSTEM THEIR QUALITY
}

\author{
V. O. Velychko ${ }^{1}$, A. V. Hrymak ${ }^{2}$, L. V. Kurilas ${ }^{1}$, T. Ye. Senyshyna ${ }^{1}$ \\ ${ }^{1}$ State Scientific Research Control Institute of Veterinary Medical Products and Feed Additives \\ 11, Donetska str., Lviv, 79019, Ukraine \\ ${ }^{2}$ Lviv National University of Veterinary Medicine and Biotechnology \\ names after S.Z.Gzhytsky \\ 50, Pekarska str., Lviv, 79010, Ukraine
}

\section{S U M M A R Y}

The quality of veterinary medicine products produced by domestic enterprises, its competitiveness, today, unfortunately, is not yet a strong and unpromising indicator of individual enterprises. At the same time it is necessary to recognize that the reforms carried out in the country orient the producers of products, including for veterinary medicine, to reassess their outdated tendencies towards the improvement of production, which would ensure the production of quality and safe products for veterinary medicine. first of all, about veterinary preparations, the use of which would effectively ensure the welfare of livestock, poultry and other industries, contribute to the preservation of human health and ecological balance of the natural environment. And even at the enterprises of veterinary medicine came the understanding that the introduction of effective systems of quality management of products will be able to ensure the stable position of enterprises both in the field of production and in the market of products for veterinary medicine. Of course, the implementation of an effective quality management system requires a high level of professionalism, mastering modern methods and technologies, and most importantly an appropriate level of staff qualification. This will help to ensure that the very process of developing new veterinary preparations, respectively their testing and production, will be based on the basic principles of the quality system, which will ensure that the products are manufactured and controlled in accordance with strict compliance with the requirements of the regulatory technical documentation and standards.

The market for veterinary medicine products is already orienting manufacturers to the production of quality, efficient and competitive products, in a new way, taking into account foreign experience to consider contacts with all entities involved in the production and supply of veterinary drugs. In this important role is given to marketing, which accompanies production, helps him to organize and manage not only production, but also the sale of manufactured products. It is marketing that can provide relevant to the market situation, planning the range of products, its characteristics, evaluating competitors, formulate proposals and analyze consumer demand. It is clear that the quality of veterinary preparations is ensured by a set of measures, including market principles. The main ones, including mechanisms for quality control of veterinary products are regulated in the Laws of Ukraine "On Veterinary Medicine", "On Basic Principles of State Supervision (Control) in the Field of Economic Activity", "On Consumer Protection", "On Withdrawal, Processing, Processing, utilization, destruction or further use of substandard and dangerous products ", licensed conditions for conducting business activities in the production of veterinary preparations," Regulations on the registration (re-registration) of veterinary drugs, substances, $g$ of feed and feed additives in Ukraine. The main parameters of these documents are already taken into account in the harmonization of legislative and regulatory documents of Ukraine.

Keywords: QUALITY MANAGEMENT SYSTEM, LICENSING, MARKET, ENTERPRISE, PRODUCTION, CONTROL, MARKETING SUPPORT. 


\title{
МАРКЕТИНГОВАЯ СОСТАВЛЯЮЩАЯ ПРОИЗВОДСТВА ВЕТЕРИНАРНЫХ ПРЕПАРАТОВ ПРИ ФУНКЦИОНИРОВАНИИ СИСТЕМЫ УПРАВЛЕНИЯ ИХ КАЧЕСТВОМ
}

\author{
В. О. Величко ${ }^{1}$, А. В. Гримак², Л. В. Курилас ${ }^{1}$, Т. Е. Сенишина \\ ${ }^{1}$ Государственный научно-исследовательский контрольный институт ветеринарных \\ препаратов и кормовых добавок \\ ул. Донецкая, 11, г. Львов, 79019, Украина \\ ${ }^{2}$ Львовський национальный университет ветеринарной медицины и биотехнологий \\ имени С. 3. Гжицкого \\ ул. Пекарская, 50, г. Львов, 79010, Украина
}

\section{А Н Н О Т А ЦИ Я}

Качество продукции для ветмедицины, которую производят отечественные предприятия, ее конкурентоспособность, сегодня к сожалению, еще не является сильным и безапелляционным показателем отдельных предприятий. В то же время необходимо признать что реформы, которые проводятся в государстве ориентируют производителей продукции, в т.ч. и для ветеринарной медицины к переоценке своих устаревших тенденций в сторону усовершенствования производств, которое обеспечивало бы производство качественной и безопасной продукции для ветмедицины, идет речь в первую очередь о ветеринарных препаратах, применение которых эффективно обеспечивало бы благополучие животноводства, птицеводства и других отраслей, способствовало сохранению здоровья людей и экологического равновесия естественной среды. И на предприятиях ветмедицини пришло понимание того, что само внедрение эффективных систем управления качеством продукции способно обеспечить стойкое положение предприятий как в сфере производства так и на рынке продукции для ветмедицини. Конечно, внедрение эффективной системы управление качеством требует высокого профессионализма, освоения современных методов и технологий, а главное соответствующего уровня квалификации персонала. Это будет способствовать потому, что уже сам процесс разработки новых ветеринарных препаратов, соответственно и их апробации и производство будет базироваться на основных принципах системы качества, которая будет гарантировать, что выработанная продукция производится и контролируется в соответствии с четким соблюдением требований нормативно-технической документации и стандартов.

Рынок продукции для ветмедицини уже ориентирует производителей на производство качественной, эффективной и конкурентоспособной продукции, по-

новому, с учетом зарубежного опыта рассматривать контакты со всеми субьектами, какие причастные к производству и поставкам в обращение ветеринарных препаратов. В этом важная роль отводится маркетингу, который сопровождает производство, помогает его организовать и управлять не только производством, но и сбытом выработанной продукции. Именно маркетинг может давать соответствующие на ситуацию на рынке, планирование ассортимента продукции, ее характеристики, оценки конкурентов формирует предложения и анализирует потребительский спрос. Понятно, что качество ветеринарных препаратов обеспечивается комплексом мероприятий, в т.ч. и принципами рынка. Основные из них, в частности и механизмы контроля качества ветпрепаратов регламентированы в Законах Украины «О ветеринарной медицине», «Об основных принципах государственного надзора (контроля) в сфере хозяйственной деятельности», «О защите прав потребителей», «Об исключении из обращения, переработку, утилизацию, уничтожение или дальнейшее использование не качественной и опасной продукции», лицензионных условиях осуществления хозяйственной 
деятельности из производства ветеринарных препаратов, «Положения о регистрации (перерегистрацию) ветеринарных препаратов, субстанций, готовых кормов и кормовых добавок в Украине». Основные параметры этих документов уже учитываются при гармонизации законодательных и нормативно-регламентирующих документов Украины.

КлючевЫе слова: СИСТЕМА УПРАВЛЕНИЕ КАЧЕСТВОМ, ЛИЦЕНЗИРОВАНИЕ, РЫНОК, ПРЕДПРИЯТИЕ, ПРОИЗВОДСТВО, КОНТРОЛЬ, МАРКЕТИНГОВОЕ СОПРОВОЖДЕНИЕ.

\section{Л I T E P A T У P A}

1. Закон України «Про ветеринарну медицину», № 2498-Х від 25.06.1992 p.

2. Закон України «Про основні засади держаного нагляду (контролю) у сфері господарської діяльності», № 877 від 05.04.2007 р.

3. Закон України «Про захист прав споживачів» № 30 від 1991 р.

4. Ліцензійні проводження умови господарської діяльності з виробництва ветеринарних препаратів.

5. Закон України «Про стандартизацію» № 2581-VIII від 02.10.2018 p.

6. Положення «Про випробувальний центр ДНДКІ ветеринарних препаратів та кормових добавок», затверджене НААН, січень 2019 р.

7. Величко B. О. Маркетингові дослідження асортименту ветпрепаратів на ринку продукції для ветмедицини // В. О. Величко, Л. І. Фляк, Т. Є. Сенишина // НТБ ДНДКІ ветпрепаратів та кормових добавок. - Львів, 2015. - Вип. 16, № 1, - С. 192 - 196.

8. Коцюмбас I. Я. Метод оцінювання ефективності системи управління якістю продукції на підприємствах ветмедицини. Методичні рекомендації // І. Я. Коцюмбас, В. О. Величко, Т. I. Тесарівська // Методичні рекомендації. - Львів, - 2015. - С. 14/

\section{References}

1. Zakon Ukrayiny «Pro veterinarnu medytcynu», № 2498-X vid 25.06.1992.(in Ukrainian).

2. Zakon Ukrayiny «Pro osnovni zasady nahlyadu (kontrolyu) u sferi hospodars'koyi diyal'nosti», № 877 vid 05.04.2007. .(in Ukrainian).

3. Zakon Ukrayiny «Pro zakhyst prav spozhyvachiv», № 30 vid 1991. (in Ukrainian).

4.Litsenziyni provodzhennya umovy hospodars'koyi diyal'nosti z vyrobnytstva veterynarnerh preparativ. (in Ukrainian).

5. Zakon Ukrayiny «Pro standartezatsiyu», № 2581- VIII from 02.10.2018. (in Ukrainian).

6 . Polozhennea «Pro vyprobuval'nyy tsentr DNDKI veterynarnykh preparativ ta kormovykh dobavok»,zatverdzhene NAAN sichen, 2019. (in Ukrainian).

7. Velychko V. O. Marketynhovi doslidzhennay asortymentu vetpreparativ na rynku produktsiyi dlya vetmedytsyny / V. O. Velychko, L.I. Flyak, T. E. Senyshyna // NTB DNDKI veterynarnykh preparativ ta kormovykh dobavok, - Lviv, - 2015 - Vyp. 16, № 1, S. 192 - 196. (in Ukrainian).

8. Kotsyumbas I. Ya. Metod otsinyuvannya efektyvnosti systemy upravlinnya yakistyu produktsiyi na pidpryyemstvakh vetmedytsyny. Metodechni rekomendatsiyi / I. Ya. Kotsyubbas V. O. Velychko, U. SH. Tesarivska // Metodechni rekomendatsiyi - Lviv, - 2015, p. 14 (in Ukrainian).

Рецензент - Д. Ф. Гуфрій, д. вет. н., професор, Львівський національний університет ветеринарної медицини та біотехнологій імені С. З. Гжицького. 